\title{
PEMBENTUKAN PERATURAN DAERAH YANG RESPONSIF MELALUI INISIATIF DPRD KOTA MATARAM
}

\author{
ESTABLISHMENT OF RESPONSIVE REGIONAL \\ REGULATIONS THROUGH THE MATARAM CITY DPR \\ INITIATIVE \\ Darmini \\ Dosen Tetap Yayasan Sekolah Tinggi Manajemen Informatika Komputer Mataram \\ Email : darmini.cc@gmail.com
}

Naskah diterima : 19/05/2018; direvisi : 04/08/2018; disetujui : 13/08/2018

\begin{abstract}
This research aimed to determine, assess and understand the process of Establishment of Regional Regulation Responsive through Initiative of DPRD Kota Mataram. This research uses the literature or the secondary of data as the data initially. The results showed that in the process of Establishment of Regional Regulation Responsive through Initiative of DPRD Kota Mataram at the level of implementation is already providing space for public participation in the formation, but have a very fundamental difference, which the Regional Regulations derived from the initiative of DPRD Kota Mataram tend to be characterized by responsive because it is aspirational tend will respond to the needs of the community (bottom up) and the manufacturing process was participatory, as well as in terms of its legal interpretation of the products provide little opportunity for the government to make its own interpretation through various implementing regulations. While the Regional Regulations proposed by the Regional Head orthodox tend character because they are positivist-instrumentalist, meaning contains material that reflects the vision of social and political power holders or contains material which is more of a tool for realizing the will and interests of government programs (top down). Then the manufacturing process that is centralized, as well as in terms of its legal interpretation of the product gives a wide opportunity to the government to make various interpretations by various regulatory advanced.
\end{abstract}

\section{Keyword: Regional, Regulation, Responsive}

\begin{abstract}
Abstrak
Penelitian ini bertujuan untuk mengetahui, menilai dan memahami proses Pembentukan Regulasi Daerah yang Responsif melalui Inisiatif DPRD Kota Mataram. Penelitian ini menggunakan literatur atau data sekunder sebagai data pada awalnya. Hasil penelitian menunjukkan bahwa dalam proses Pembentukan Regulasi Daerah Responsif melalui Inisiatif DPRD Kota Mataram pada tataran pelaksanaannya sudah memberikan ruang bagi partisipasi masyarakat dalam formasi, namun memiliki perbedaan yang sangat mendasar, dimana Peraturan Daerah tersebut berasal dari inisiatif DPRD Kota Mataram cenderung ditandai dengan responsif karena cenderung aspirasional akan merespon kebutuhan masyarakat (bottom up) dan proses pembuatannya partisipatif, serta dalam hal interpretasi hukum produknya memberikan sedikit kesempatan untuk pemerintah membuat interpretasinya sendiri melalui berbagai peraturan pelaksanaan. Sedangkan Peraturan Daerah yang diajukan oleh Kepala Daerah cenderung ortodoks karena bersifat positivisinstrumentalis, artinya berisi materi yang mencerminkan visi pemegang kekuasaan sosial dan politik atau mengandung materi yang lebih merupakan alat untuk
\end{abstract}


mewujudkan kemauan dan kepentingan program pemerintah. (atas bawah). Kemudian proses manufaktur yang terpusat, serta dalam hal interpretasi hukum produknya memberi kesempatan luas kepada pemerintah untuk melakukan berbagai interpretasi oleh berbagai peraturan yang maju.

\section{Kata kunci: Daerah, Peraturan, Responsif PENDAHULUAN}

Indonesia adalah Negara Hukum,
dimana supremasi hukum sangat
dijunjung tinggi, oleh karenanya
pembangunan hukum di Indonesia
diarahkan pada terciptanya Tata Hukum
Nasional Indonesia, salah satunya
adalah di bidang hukum pemerintahan.
Majelis Permusyawaratan Rakyat kepada
supremasi konstitusi (amandemen
Undang-Undang Dasar Negara Republik
Indonesia Tahun 1945) termasuk
perubahan-perubahan bagian lain yang
cukup banyak dan fundamental sangat
berpengaruh dan membawa implikasi
yuridis pada sistem ketatanegaraan.

Dari aspek penyelenggaraan pemerintahan, perubahan yang terjadi adalah adanya amandemen UndangUndang Dasar Negara Republik Indonesia Tahun 1945 Pasal 18 yang intinya memberikan kewenangan kepada pemerintah daerah untuk mengatur dan menjalankan roda Pemerintahan Daerah secara otonomi seluas-luasnya, kecuali urusan pemerintahan yang oleh UndangUndang ditentukan sebagai urusan pemerintah pusat.

Berdasarkan Undang-Undang Nomor 32 Tahun 2004 maka pemerintahan daerah diberikan kewenangan melalui prinsip otonomi luas, nyata dan bertanggung jawab, meskipun tidak semua urusan harus diserahkan ke daerah. Urusan-urusan yang tidak diserahkan kepada daerah adalah urusan Luar Negeri, Agama, Pertahanan, Keamanan, Peradilan, Moneter, dan Fiskal Nasional. Maka dengan prinsip otonomi yang seluas-luasnya tersebut, daerah berwenang mengatur dan mengurus rumah tangganya sendiri dalam wadah Negara Kesatuan Republik Indonesia.

Untuk mengatur urusan-urusan yang menjadi otonominya, pemerintah daerah diberi kewenangan untuk membentuk Peraturan Daerah seperti diatur dalam Pasal 136 Undang-Undang Nomor 32 Tahun 2004 yang menyatakan:

(1) Peraturan Daerah ditetapkan oleh Kepala Daerah setelah mendapatkan persetujuan bersama DPRD.

(2) Peraturan Daerah dibentuk dalam rangka penyelenggaraan otonomidaerah Provinsi/ Kabupaten/ Kota dan tugas pembantuan.

(3) Peraturan Daerah sebagaimana dimaksud pada ayat (1) merupakan penjabaran lebih lanjut dari Peraturan Perundang-undangan yang lebih tinggi denganmemperhatikancirikhasmasingmasing Daerah.

(4) Peraturan Daerah sebagaimana dimaksud pada ayat (1) dilarang bertentangan dengan kepentingan Undang-Undang yang lebih tinggi.

(5) Peraturan Daerah sebagaimana dimaksud pada ayat (1) berlaku setelah diundangkannya dalam lembaran Daerah.

Sejalan dengan hal tersebut, dalam ketentuan Pasal 350 huruf (a) UndangUndang Nomor 27 Tahun 2009 tentang Majelis Permusyawaratan Rakyat, Dewan Perwakilan Rakyat, Dewan Perwakilan Daerah, dan Dewan Perwakilan Rakyat Daerah, yang pada pokoknya mengamanatkan bahwa Anggota DPRD Kabupaten/ Kota mempunyai hak untuk mengajukan rancangan peraturan daerah Kabupaten/ Kota.

Menurut pendapat Solly Lubis, yang menyatakan bahwa selaku Wakil Rakyat yang kepentingannya mereka wakili dan salurkan, harus berpegang teguh 
pada prinsip bahwa mereka memainkan peranan ganda sekaligus, yakni $:^{1}$

1) Meramu aspirasi rakyat, baik secara songsong bola ataupun jemput bola (menunggu rakyat datang mengunjungi DPRD atau anggota DPRD itu turun ke lapanganlangsungdialogdenganrakyat).

2) Menyalurkan aspirasi rakyat ke forumforum yang ada di DPRD, yaitu : Rapat Komisi, Rapat Panitia Musyawarah, Rapat Pansus, Rapat Panitia Anggaran, Rapat Paripurna, dan Pertemuan antara Legislatif dengan Eksekutif dan berusaha sedapat mungkin agar PerdaPerda yang diterbitkan benar-benar menggambarkan tersalurnya aspirasi rakyat itu.

Hal inilah yang memberikan landasan hukum dan wewenang kepada anggota DPRD untuk menggunakan haknya dalam mengajukan rancangan Peraturan daerah sesuai dengan kehendak atau masukan dari masyarakat, karena DPRD merupakan representasi dari masyarakat yang mereka wakili.

Keikutsertaan masyarakat dalam memberikan masukan terhadap pembentukan peraturan Perundangundangan merupakan suatu cerminan dari sebuah Negara Demokrasi dimana keikutsertaan rakyat merupakan suatu hal yang niscaya, meskipun rakyat sudah diresperentasikan oleh Wakil-wakil di lembaga Perwakilan Rakyat (DPR dan DPRD).

Walaupun dalam pembentukan suatu Peraturan Daerah tersebut berasal dari inisiatif DPRD tidak berarti suatu Rancangan Peraturan Daerah tersebut tidak akan berpotensi terjadi penyimpangan substansinya pada proses pembahasannya bersama Kepala Daerah, karena masyarakat sudah tidak dilibatkan lagi kecuali para Legislator membuka ruang publik bagi masyarakat untuk didengarkan pendapatnya dalam

${ }^{1}$ Lubis Solly, 2009, Ilmu Pengetahuan Perundang-undangan, CV. Mandar Maju, Bandung, hlm. 60. bentuk Public Hearing. Jika tidak ada ruang publik tersebut maka masyarakat tidak memungkinkan lagi untuk terlibat. Tahapan terakhir proses legislasi tersebut adalah sebuah black box, yaitu proses pengajuan draft Peraturan Daerah untuk dibahas dalam sidang paripurna sampai pengundangannya dalam lembaran daerah. Pada tahapan ini, proses bersifat politis dan sangat menentukan nasib dari peraturan yang diajukan tersebut. Karenanya pada setiap tahapan legislasi sangat berpotensi untuk terjadinya penyimpangan substansi Peraturan Daerah.

Dari uraian tersebut di atas maka dapat dirumuskan permasalahan sebagai berikut "Bagaimana proses pembentukan Peraturan Daerah yang responsif melalui Inisiatif DPRD Kota Mataram ?".

Penelitian ini merupakan penelitian hukum yuridis sosiologis (empiris), yaitu suatu penelitian yang menggunakan bahan kepustakaan atau data sekunder sebagai data awalnya kemudian dilanjutkan dengan data primer atau data lapangan. Data sekunder diperoleh melalui studi dokumen dan data primer diperoleh melalui pengamatan (observasi) dan wawancara (interview).

\section{PEMBAHASAN}

Sehubungan dengan tulisan ini membahas pembentukan peraturan daerah melalui inisiatif DPRD Kota Mataram, maka sangat relevan apabila dikaji tentang teori perundang-undangan sebagai salah satu upaya untuk menghasilkan peraturan yang baik.

Teori perundang-undangan merupakan bagian dari ilmu pengetahuan perundangundangan, dimana Menurut pendapat Attamimi yang dikutip oleh Maria farida menyatakan dalam bukunya, ${ }^{2}$ bahwa ilmu pengetahuan perundang-undangan merupakan ilmu yang berhubungan

${ }^{2}$ Maria Soeprapto Farida Indrati, 2007 Ilmu Perundang-Undangan, jenis, fungsi dan materi muatan. Kanisius, Yogjakarta, hlm 8-9. 
dengan politik dan sosiologi, secara garis besar dapat dibagi menjadi dua bagian besar, yaitu :

1. Teori Perundang-undangan (Gesetzgebungstheorie), yang berorientasi pada materi kejelasan dan kejernihan makna atau pengertianpengertian (begripsvorming dan begripsverheldering), dan bersifat kognitif (erklärungsorientiert).

2. Ilmu perundang-undangan (Gesetzgebungslehre), yang berorientasi pada melakukan perbuatan dalam hal pembentukan peraturan perundangundangan, dan bersifat normatif (handlungsorientiert).

Lebih lanjut, peraturan perundangundangan yang baik, harus memenuhi syarat sebagai berikut : ${ }^{3}$

1. Landasanfilosofis(filosofischegrondslag) Suatu rumusan peraturan perundang-undangan harus mendapatkan pembenaran (rechtvaardiging) yang dapat diterima jikadikajisecarafilosofis.Pembenaranitu harus sesuai dengan cita-cita kebenaran (idéederwaarheid), dancita-citakeadilan (idée der gerechtigheid), dan cita-cita kesusilaan (idée der zedelijkheid).

2. Landasan sosiologis (socologische grondslag)

Suatu peraturan perundangundangan harus sesuai dengan keyakinanumumataukesadaranhukum masyarakat.Olehkarenaitu,hukumyang dibentuk harus sesuai dengan hukum yang hidup (living law) di masyarakat.

3. Landasan yuridis (rechtsgrond)

Suatu peraturan perundangundangan harus mempunyai landasan hukum atau dasar hukum atau legalitas yangterdapatdalamketentuanyanglebih tinggi.Landasanyuridisdapatdibedakan menjadi dua sebaga berikut :

${ }^{3}$ Jazim Hamidi, Et.al., Optik Hukum Peraturan Daerah Yang Bermasalah, PT. Prestasi Pustakaraya, Jakarta, hlm 7-8. a. landasanyuridisyangberaspekformal berupa ketentuan yang memberikan wewenang(bevoegdheid) kepadasuatu lembaga untuk membentuknya, dan

b. landasan yuridis yang beraspek material berupa ketentuan tentang masalah atau persoalan yang harus diatur.

4. Landasan politis, ekologis, medis, ekonomis, dan lain-lain menyesuaikan dengan jenis atau obyek yang diatur oleh peraturan perundang-undangan - Terdapat suatu pertimbangan lainnya yang perlu dipertimbangkan oleh pembuat peraturan perundangundangan yaitu pada dasarnya sebuah peraturan perundang-undangan itu dibuat harus didukung dengan data riset yang akurat (sering disebut pembuatan peraturan perundang-undangan yang berbasis riset).

Sebagai salah satu sumber hukum, peraturan perundang-undangan tidak selalu menjunjung tinggi keadilan, sebagai perwujudan nilai-nilai tertentu dalam masyarakat ${ }^{4}$ serta demokrasi dan kepentingan masyarakat luas, karena hukum bukanlah subsistem yang otonom dan netral tetapi sebaliknya selalu dipengaruhi oleh banyak faktor dan kepentingan. Di dalam kajian ilmu hukum paling tidak ada 3 faktor yang menjadi parameter sebuah peraturan perundang-undangan dapat berlaku secara baik, yakni mempunyai dasar keberlakuan yuridis, sosiologis, dan filosofis. ${ }^{5}$

Mahfud, $\mathrm{MD}^{6}$, mengemukakan bahwa produk hukum yang berkarakter

${ }^{4}$ M. Yazid Fathoni, Konsep Keadilan Dalam Pengelolaan dan Pemanfaatan Sumber Daya Alam Menurut Undang-Undang Pokok Agraria Tahun 1960, Jurnal IUS (Hukum dan Keadilan), Vol. I, No. 1, April 2013, http://jurnalius.ac.id/ojs/index.php/jurnalIUS/article/ view/225/197, diakses tanggal 6 April 2018. hlm. 46

${ }^{5}$ Hamzah Halim dan Putera, Kemal Redino Syahrul, 2009, Cara Praktis Menyusun dan Merancang Peraturan Daerah, Kencana Prenada Media Group, Jakarta, hlm $2-4$.

${ }^{6}$ Moh. Mahfud MD, 2011, Membangun Politik Hukum Menegakkan Konstitusi, Rajawali Pers PT. Raja 
responsif, proses pembuatannya bersifat partisipatif, yakni mengundang sebanyak-banyaknya partisipasi masyarakatmelaluikelompok-kelompok sosial dan individu di dalam masyarakat. Sedangkan proses pembuatan hukum yang berkarakter ortodoks bersifat sentralistik dalam arti lebih didominasi olehlembaga negara terutama pemegang kekuasaan eksekutif.

Oleh karena dalam membentuk peraturan daerah telah diatur dalam Pasal 14 Undang-Undang Nomor 12 Tahun 2011 tentang Pembentukan Peraturan Perundang-undangan, yang menentukan bahwa materi muatan PeraturanDaerahProvinsidanPeraturan Daerah Kabupaten/Kota berisi materi muatan dalam rangka penyelenggaraan otonomi daerah dan tugas pembantuan serta menampung kondisi khusus daerah dan/atau penjabaran lebih lanjut Peraturan Perundang-undangan yang lebih tinggi.

Otonomi daerah merupakan esensi pemerintahan desentralisasi. Istilah otonomi berasal dari penggalan dua kata bahasa yunani, yakni autos yang berarti sendiri dan nomos yang berarti Undang-Undang. Otonomi bermakna membuat perundang-undangan sendiri (zelfwetgeving), namun dalam perkembangannya, konsepsi otonomi daerah selain mengandung arti zelfwetgeving (membuat perda-perda), juga utamanya mencakup zelfbestuur (pemerintahan sendiri). ${ }^{7}$

Dalam Pasal 1 angka 5 UndangUndang Nomor 32 Tahun 2004 tentang Pemerintahan Daerah, menyatakan bahwa:

"Otonomi daerah adalah hak, wewenang, dan kewajiban daerah otonom untuk mengatur dan mengurus sendiri urusan pemerintahan dan kepentingan

Grafindo Persada, Jakarta, 2011, hlm.33

7 Ni' Matul Huda, 2012, Hukum Pemerintahan Di Daerah, Nusa Media, Bandung, hlm. 83. masyarakat setempat sesuai dengan peraturan perundang-undangan".

Kemudian dalam Pasal 1 angka (6) Undang-Undang Nomor 32 Tahun 2004 tentang Pemerintahan Daerah, menjelaskan bahwa yang dimaksud dengan daerah otonom, adalah "kesatuan masyarakat hukum yang mempunyai batas-batas wilayah yang berwenang mengatur dan mengurus urusan pemerintahan dan kepentingan masyarakat setempat menurut prakarsa sendiriberdasarkan aspirasi masyarakat dalam sistem Negara Kesatuan Republik Indonesia".

Para ahli memberi pengertian yang beragamtentangkonsepotonomidaerah, antara lain sebagaimana dikemukakan oleh Sarundajang 8 , menjelaskan kata "otonomi atau autonomy" berasal dari bahasa Yunani, auto yang berarti sendiri dan nomous yang berarti hukum atau peraturan.

Kemudian Utang Rosidin ${ }^{9}$, yang memberi pengertian tentang otonomi adalah pemerintahan yang mampu menyelenggarakan pemerintahan, yang dituangkan dalam peraturan sendiri, sesuai dengan aspirasi masyarakatnya.

Sementara Suriansyah Murhani ${ }^{10}$, yang memberi pengertian tentang otonomi adalah pembagian kekuasaan antarapemerintah pusatdan pemerintah daerah yang dilaksanakan melalui asas desentralisasi, dimana pemerintah pusat mengalihkan kewenangan atau urusan yang secara tunggal menjadi pemegang kekuasaan tunggal dalam Negara Kesatuan kepada Daerah agar pemerintahan tersebutdiaturdandiurus sendiri sesuai dengan prinsip-prinsip administrasi pemerintahan.

\footnotetext{
${ }^{8}$ Sarundajang, 2000, Arus Balik Kekuasaan Pusat ke Daerah, Pustaka Sinar Harapan, Jakarta, hlm. 33.

${ }^{9}$ Rosidin, 2010, Utang, Otonomi Daerah dan Desentralisasi, CV. Pustaka Setia, Bandung, hlm. 85.

${ }^{10}$ Suriansyah Murhani, 2008, Aspek Hukum Pengawasan Pemerintah Daerah, Laksbang Mediatama, Yogyakarta, hlm.7.
} 
Kemudian dalam pelaksanaan otonomi daerah tersebut, ada tiga asas yang digunakan, yaitu asas desentralisasi, dekonsentrasi, dan tugas pembantuan. Dalam Pasal 1 angka 7 Undang-Undang Nomor 32 Tahun 2004 tentang Pemerintahan Daerah, yang dimaksud dengan Desentralisasi adalah "penyerahan wewenang pemerintahan oleh pemerintah kepada daerah otonom untuk mengatur dan mengurus urusan pemerintahan dalam sistem Negara Kesatuan Republik Indonesia”.

Kemudian Pasal 1 angka 8 UndangUndang Nomor 32 Tahun 2004 tentang Pemerintahan Daerah, yang dimaksud dengan Dekonsentrasi adalah "pelimpahan wewenang pemerintahan oleh pemerintahkepada Gubernur sebagai wakil pemerintah dan/atau kepada instansi vertikal di wilayah tertentu".

Sedangkan Pasal 1 angka 9 UndangUndang Nomor 32 Tahun 2004 tentang Pemerintahan Daerah, yang dimaksud dengan tugas pembantuan adalah "penugasan dari pemerintah kepada daerah dan/atau desa dari Pemerintah ProvinsikepadaPemerintah Kabupaten/ Kotadan/atauDesasertadariPemerintah Kabupaten/Kota kepada desa untuk melaksanakan tugas tertentu".

Sesungguhnya substansi dari otonomi daerah tersebut adalah terletak pada asas desentralisasi, sehingga setiap daerah dapat atau boleh menyelenggarakan kewenangan pemerintahan tergantung atas kebutuhan dan kemampuan daerah yang bersangkutan serta dilaksanakan atas dasar ketentuan umum yang telah digariskan oleh Pemerintah Pusat demi menjaga nilai dan keutuhan Negara Kesatuan.

Peraturan Daerah adalah salah satu bentuk peraturan pelaksana Undang-Undang. Pada pokoknya, kewenangannya mengatur bersumber dari kewenangan yang ditentukan oleh pembentuk Undang-Undang. Akan tetapi, dalam hal-hal tertentu, Peraturan Daerah juga dapat mengatur sendiri halhal yang meskipun tidak didelegasikan secara eksplisit kewenangannya oleh Undang-Undang, tetapi dianggap perlu diatur oleh daerah untuk melaksanakan otonomi daerah yang seluas-luasnya sebagaimanadimaksudolehPasal 18ayat (2), (5), dan (6) Undang-Undang Dasar Negara Republik Indonesia Tahun 1945. Bahkan, dalam Peraturan Daerah juga dapatdimuatmengenaiketentuanpidana seperti halnya dalam Undang-Undang. Dalam Pasal 15 Undang-Undang Nomor 12 Tahun 2011 tentang Pembentukan Peraturan Perundang-Undangan, ditentukan, "Materi muatan mengenai ketentuan pidana hanya dapat dimuat dalam Undang-Undang, Peraturan Daerah Provinsi, atau Peraturan Daerah Kabupaten/Kota".

Namun demikian, pengaturan tentang perancangan Peraturan Daerah yang diatur di dalam UndangUndang Nomor 12 Tahun 2011 tentang Pembentukan Peraturan Perundangundangan, masih sangat umum sehingga didalamPasal59danberdasarkanPasal63 Undang-Undang tersebutberlaku secara mutatis mutandis terhadap penyusunan Peraturan Daerah Kabupaten/Kota, yang pada pokoknya memerintahkan mengenai tata cara penyusunan Rancangan Peraturan Daerah Provinsi yangberasaldariGubernurdiaturdengan Peraturan Presiden. Akan tetapi hingga saatiniPeraturanPresidenterkaitdengan Penyusunan Peraturan Daerah belum ditetapkan. Untuk mengisi kekosongan peraturan, maka pengaturan lebih rinci terkait penyusunan Produk Hukum Daerah masih mengacu pada Peraturan Menteri Dalam Negeri Republik Indonesia Nomor 53 Tahun 2011 tentang Pembentukan Produk Hukum Daerah. Sedangkan untuk rancangan Peraturan Daerah yang diajukan oleh 
Inisiatif DPRD sebagaimana Pasal 60 dan berdasarkan Pasal 63 UndangUndang Nomor 12 Tahun 2011 tentang Pembentukan Peraturan Perundangundangan, berlaku secara mutatis mutandis terhadap penyusunan Peraturan Daerah Kabupaten/Kota, yang pada pokoknya menyatakan bahwa ketentuanlebihlanjutmengenaitatacara mempersiapkan Rancangan Peraturan Daerah Provinsi yang diajukan oleh anggota, komisi, gabungan komisi, atau alat kelengkapan DPRD Provinsi yang khusus menangani bidang legislasi, diatur dalam Peraturan DPRD Provinsi.

Pembentukan Peraturan Daerah merupakan kewenangan Kepala Daerah bersama-sama dengan DPRD, dimana inisiatifpembentukan PeraturanDaerah dapatberasaldarikepalaDaerah maupun inisiatif dari Dewan Perwakilan Rakyat Daerah (DPRD). Untuk pembentukan Peraturan Daerah yang berasal dari inisiatif DPRD Kota Mataram merujuk pada ketentuan Peraturan Dewan PerwakilanRakyatDaerah(DPRD) Kota Mataram Nomor 1 Tahun 2010 tentang Tata Tertib Dewan Perwakilan Rakyat Daerah Kota Mataram. Hal ini telah sesuai dengan amanat Pasal 60 dan Pasal 63 Undang-Undang Nomor 12 Tahun 2011 tentang Pembentukan Peraturan Perundang-undangan, berlaku secara mutatis mutandis terhadap penyusunan Peraturan Daerah Kabupaten/Kota, sebagaimana telah disampaikan sebelumnya.

Dalamtahapan rancanganPeraturan Daerah baik yang berasal dari kepala daerahmaupunyangberasaldariinisiatif DPRD memiliki mekanisme yang berbeda dimana tahapan penyusunan Rancangan Peraturan Daerah yang berasal dari Kepala Daerah, maka Walikota Mataram memerintahkan kepada pimpinan SKPD menyusun Rancangan Perdaberdasarkan Prolegda. selanjutnya Pimpinan SKPD menyusun
Rancangan Perda dengan disertai naskah akademik dan/atau penjelasan atau keterangan yang memuat pokok pikiran dan materi muatan yang diatur. Kemudian setelah rancangan tersebut disusun oleh Satuan Kerja Perangkat Daerah (SKPD) terkait maka selanjutnya diajukan kepada Bagian Hukum Setda Kota Mataram untuk untuk pengharmonisasian, pembulatan, dan pemantapan konsepsi terhadap Rancangan Peraturan Daerah yang telah disusun. Kemudian Bagian Hukum Setda Kota Mataram menjadwalkan kegiatan konsultasi publik terhadap Rancangan Peraturan Daerah tersebut, halinidimaksudkankepada masyarakat, akademisi, organisasi yang terkait untuk menyampaikan aspirasi dan memberikan kritikan, masukan baik secara lisan maupun tertulis. Setelah proses penyusunan telah selesai dilaksanakan, maka Walikota Mataram menyampaikan Rancangan Perda tersebut kepada pimpinan DPRD untuk dilakukan pembahasan.

Rancangan Peraturan Daerah yang berasal Kepala Daerah dalam hal ini yang diajukan oleh Satuan Kerja Perangkat Daerah (SKPD) terkait cenderung dihajatkan untuk melaksanakan perintah peraturan perundangundangan lebih tinggi, rencana pembangunan daerah, penyelenggaraan otonomi daerah dan tugas pembantuan, dimana tidak semua didahului dengan naskah akademik, adapun ketentuan yang mengamanatkan mengenai disertainya naskah akademik dalam penyusunan Rancangan Peraturan Daerah dimuat dalam Pasal 56 ayat (2) dan Pasal 63 Undang-Undang Nomor 12 Tahun 2011 tentang Pembentukan Peraturan Perundang-undangan, berlaku secara mutatis mutandis terhadap penyusunan Peraturan Daerah Kabupaten/Kota, yang pada pokoknya menyatakan bahwa : 
1) Rancangan Peraturan Daerah Provinsi dapat berasal dari DPRD Provinsi atau Gubernur.

2) Rancangan Peraturan Daerah Provinsi sebagaimana dimaksud pada ayat (1) disertai dengan penjelasan atau keterangan dan/atau Naskah Akademik.

Pelaksanaan Undang-Undang Nomor 12 Tahun 2011 tentang Pembentukan Peraturan Perundangundangan telah memiliki kekuatan hukum mengikat dan efektif dilaksanakan sejak diundangkan dalam Lembaran Negara Republik Indonesia tanggal 12 Agustus 2011. Akan tetapi penyusunan Rancangan Peraturan Daerah yang disertai dengan naskah akademik hanya diterapkan pada penyusunan Peraturan Daerah Kota Mataram Nomor 7 Tahun 2012 tentang PajakBumidanBangunanPerdesaandan Perkotaan yang ditetapkan pada tanggal 22 Juni 2012. Padahal banyak Peraturan Daerah yang ditetapkan setelah tanggal 12Agustus2011,akantetapitidakdisertai dengan naskah akademik, yakni:

1) Peraturan Daerah Kota Mataram Nomor 13 Tahun 2011 tentang Pajak Penerangan Jalan (Lembaran Daerah Kota Mataram Tahun 2011 Nomor 6 Seri B) ditetapkan pada tanggal 8 Desember 2011;

2) Peraturan Daerah Kota Mataram Nomor 14 Tahun 2011 tentang Retribusi Jasa Umum (Lembaran Daerah Kota Mataram Tahun 2011 Nomor 1 Seri C) ditetapkan pada tanggal 8 Desember 2011;

3) Peraturan Daerah Kota Mataram Nomor 15 Tahun 2011 tentang Retribusi Perizinan Tertentu (Lembaran Daerah Kota Mataram Tahun 2011 Nomor 2 Seri C) ditetapkan pada tanggal 8 Desember 2011;

4) Peraturan Daerah Kota Mataram Nomor 16 Tahun 2011 tentang
Retribusi Jasa Usaha (Lembaran Daerah Kota Mataram Tahun 2011 Nomor 3 Seri C) ditetapkan pada tanggal 8 Desember 2011;

5) Peraturan Daerah Kota Mataram Nomor 17 Tahun 2011 tentang Pengelolaan Barang Milik Daerah (Lembaran Daerah Kota Mataram Tahun 2011 Nomor 5 Seri E) ditetapkan pada tanggal 10 Desember 2011;

6) Peraturan Daerah Kota Mataram Nomor 18 Tahun 2011 Perubahan Atas Peraturan Daerah Kota Mataram Nomor 5 Tahun 2008 tentang Pembentukan Susunan Organisasi Perangkat Daerah Kota Mataram (Lembaran Daerah Kota Mataram Tahun 2011 Nomor 1 Seri D) ditetapkan pada tanggal 15 Desember 2011;

7) Peraturan Daerah Kota Mataram Nomor 19 Tahun 2011 tentang Pembentukan Susunan Organisasi dan Tata Kerja Lembaga Lain Sebagai Bagian Dari Perangkat Daerah Kota Mataram (Lembaran Daerah Kota Mataram Tahun2011 Nomor2 SeriD) ditetapkan pada tanggal 15 Desember 2011;

8) Peraturan Daerah Kota Mataram Nomor 8 Tahun 2012 tentang Pembebasan Retribusi Pelayanan Kesehatan Dasar Di Puskesmas dan Jaringannya Di Kota Mataram (Lembaran Daerah Kota Mataram Tahun 2012 Nomor 2 Seri B) ditetapkan pada tanggal 1 September 2012;

Tahapan penyusunan Rancangan Peraturan Daerah yang berasal dari inisiatif DPRD Kota Mataram, dapat diajukan oleh anggota DPRD, Komisi, Gabungan Komisi, atau Badan Legislasi Daerah,dengankegiatansebagaiberikut:

1) Pengusul menyampaikan rancangan Peraturan Daerah yang direncanakan untukdiajukansebagaiinisiatifDPRD 
Kota Mataram secara tertulis kepada Pimpinan DPRD disertai dengan penjelasan/ atau keterangan dan/ atau naskah akademik, daftar nama dan tandatangan pengusul.

2) Setelah berkas yang diajukan oleh pengusul lengkap, maka Pimpinan DPRD mendisposisikan/ memerintahkan Badan Legislasi Daerah (BALEGDA) Kota Mataram untuk melakukan kajian terhadap Rancangan Peraturan Daerah tersebut, dan hasil kajian Badan Legislasi Daerah (BALEGDA) disampaikankepadaPimpinanDPRD dan Pimpinan DPRD menyampaikan hasil kajian Badan Legislasi Daerah (BALEGDA) kepada semua anggota DPRD selambat-lambatnya 7 (tujuh) hari sebelum Rapat Paripurna Dewan Perwakilan Rakyat Daerah (DPRD).

3) Selanjutnya dilaksanakan Rapat Paripurnadalamrangkapenyampaian Usul Rancangan Peraturan Daerah HakInisiatifDewan, dengankegiatan:

a) Pengusul memberikan penjelasan;

b) Fraksi dan Anggota Dewan Perwakilan Rakyat Daerah (DPRD) lainnya memberikan pandangan; dan

c) Pengusul memberikan jawaban atas pandangan Fraksi dan anggota lainnya.

Selanjutnya dilaksanakan kegiatan untuk memutuskan usul Rancangan Peraturan Daerah, berupa :

a) Persetujuan;

b) Persetujuandenganpengubahan;atau

c) Penolakan.

Apabila diputuskan persetujuan dengan pengubahan, Pimpinan Dewan Perwakilan Rakyat Daerah (DPRD) menugaskan Komisi, Gabungan Komisi, Badan Legislasi Daerah, atau Panitia Khusus untuk menyempurnakan
Rancangan Peraturan Daerah (Raperda) tersebut.

4) Sebelum penyampaian Rancangan Peraturan Daerah melalui Inisiatif Dewan Perwakilan Rakyat Daerah (DPRD) kepada Walikota, Badan Legislasi Daerah (BALEGDA) melakukan pengharmonisasian, pembulatan dan pemantapan konsepsiRaperdaHakInisiatifDewan tersebut.

5) Setelah Badan Legislasi Daerah (BALEGDA) selesai melakukan pengharmonisasian, pembulatan dan pemantapan konsepsi Raperda Inisiatif Dewan tersebut. Maka Pimpinan DPRD Kota Mataram bersurat kepada Walikota Mataram perihal pengajuan Raperda dan disertai dengan draft Peraturan Daerah;

Berdasarkan hasil penelitian yang dilakukan, diketahui bahwa mulai sejak tahun 2011 sampai dengan tahun 2013 Anggota DPRD Kota Mataram telah menyusun rancangan peraturan daerah berdasarkan identifikasi kebutuhankebutuhan masyarakat melalui media cetak, elektronik maupun didapat pada saat anggota DPRD Kota Mataram melakukan kegiatan reses, kemudian diusulkan kepada pimpinan DPRD Kota Mataram dan diterima menjadi Raperda Inisiatif DPRD Kota Mataram, adapun sebagai berikut :

\section{a). Raperda Inisiatif Tahun 2011}

(1)Raperda tentang Tata Cara Pendirian, Pengawasan, Pengendalian dan Penyelenggaraaan Menara Telekomunikasi di Kota Mataram;

(2)Raperda tentang Penyertaan Modal Pemerintah Kota Mataram Kepada Badan Usaha Milik Daerah dan Badan Usaha Lainnya; 
(3)Raperda tentang Pengelolaan Jasa Lingkungan di Kota Mataram.

\section{b). Raperda Inisiatif Tahun 2012}

(1) Kelurahan;

(2)Raperda tentang Penerimaan Daerah Dari Sumbangan Pihak Ketiga;

(3)Raperda tentang Pencegahan dan Perlindungan Perempuan dan Anak Korban Tindak Kekerasan;

(4)Raperda tentang Peredaran Minuman Keras;

(5) Raperda tentang Pengelolaan Zakat, Infaq dan Sedakah;

(6) Raperda tentang Penanggulangan Gelandangan dan Pengemis Di Kota Mataram;

(7)Raperda tentang Penanggulangan Kemiskinan di Kota Mataram;

(8)Raperda tentang Retribusi Parkir Kendaraan Bermotor;

(9)Raperda tentang Pengelolaan Sampah;

\section{c). Raperda Inisiatif Tahun 2013}

(1)Raperda tentang Penyelenggaraan Kesejahteraan Sosial;

(2)Raperda tentang Penyelenggaraan Pendidikan Diniyah Takmiliyah;

(3)Raperda tentang Hygiene Sanitasi Pengelolaan Makanan, Minuman dan Tempat-tempat Tertentu.

Adapun khusus untuk Rancangan Peraturan Daerah yang berasal dari hak inisiatif DPRD Kota Mataram yang diajukan pada tahun 2011 sampai dengan tahun 2013 ini dilaksanakan melalui bekerjasama dengan Pihak ketiga dalam hal ini Akademisi. ${ }^{11}$

${ }^{11}$ Wawancara dengan, Abdul Salam, S.Ip., Kasubbag Persidangan dan Hubungan Masyarakat Sekretariat
Adapun kegiatan yang dilakukan mulai dari public hearing dan penyusunan Rancangan Peraturan Daerah bersama pengusul yakni Anggota DPRD Kota Mataram langsung difasilitasi dengan menghadirkan Anggota DPRD Kota Mataram, masyarakat, kelompok/ organisasi masyarakat, kelompok profesi, lembaga swadaya masyarakat yang terkait langsung dengan pembentukan Peraturan Daerah, serta akademisi yang berkompeten di bidang legal drafting. ${ }^{12}$

Di dalam Pembahasan Peraturan Daerah baik yang berasal dari kepala daerahmaupunyangberasaldariinisiatif DPRD, juga memiliki mekanisme yang berbeda, akan tetapi mekanismenya akan sama pada pembicaraan tingkat II, dimana :

a. Pembahasan Rancangan Peraturan Daerah yang berasal dari Kepala Daerah dibahas oleh DPRD Kota Mataram dan Walikota Mataram untuk mendapatkan persetujuan bersama. Adapun pembahasan RancanganPeraturanDaerahtersebut dilakukan melalui 2 (dua) tingkat pembicaraan, yaitu sebagai berikut :

1) Pembicaraan tingkat I

Pada pembicaraan tingkat I ini dilakukan sebagai berikut :

a) penjelasan kepala daerah dalam rapat paripurna mengenai Rancangan Perda;

b) pemandangan umum fraksi terhadap Rancangan Perda; dan

c) tanggapan dan/atau jawaban kepala daerah terhadap pemandangan umum fraksi.

2) Pembicaraan tingkat II

Pembicaraan pada tingkat ini, meliputi : 
a) pengambilan keputusan dalam rapat paripurna yang didahului dengan:

(1)penyampaian laporan hasil kerja pimpinan komisi/ pimpinan gabungan komisi/ pimpinan panitia khusus yang berisi pendapat fraksi dan hasil pembahasan.

(2)permintaan persetujuan dari anggota secara lisan oleh pimpinan rapat paripurna.

b) Pendapat Akhir Walikota Mataram.

Dalam hal persetujuan tersebut tidak dapat dicapai secara musyawarah untuk mufakat, keputusandiambilberdasarkansuara terbanyak.

Dalam hal rancangan Perda tidak mendapat persetujuan bersama antara DPRD dan Kepala Daerah, RancanganPerdatersebuttidakboleh diajukan lagi dalam persidangan DPRD masa itu.

c) PembahasanRancanganPeraturan Daerah yang berasal dari DPRD Kota Mataram dibahas oleh DPRD Kota Mataram dan Walikota Mataram untuk mendapatkan persetujuan bersama. Adapun pembahasan RancanganPeraturan Daerah tersebut sama halnya dengan Rancangan Peraturan Daerah yang berasal dari Kepala Daerah, dimana dilakukan melalui 2 (dua) tingkat pembicaraan, dimana hanya pada pembicaraan tingkat I saja yang berbeda, yaitu sebagai berikut :

1) Pembicaraan tingkat I

PadapembicaraantingkatIini dilakukan sebagai berikut :

a) Penjelasan pimpinan komisi, pimpinan gabungan komisi, pimpinan Balegda, atau pimpinan panitia khusus dalam rapat paripurna mengenai

Rancangan

Peraturan Daerah inisiatif DPRD Kota Mataram;

b) Dilanjutkan dengan penyampaian Pendapat Walikota Mataram terhadap Inisiatif DPRD Kota Mataram dalam Rapat Paripurna; dan

c) Kemudiandilanjutkandengan Tanggapan dan/atau jawaban fraksi terhadap pendapat Walikota Mataram.

d) Dilakukan pembahasan antara Panitia Khusus dengan Eksekutif (SKPD terkait);

2) Pembicaraan tingkat II

Pembicaraan pada tingkat ini, sama halnya dengan pembicaraan tingkat II yang sebelumnya telah dibahas pada mekanisme pembahasan untuk Rancangan Peraturan Daerah yang berasal dari Kepala Daerah.

Rancangan Perda yang telah disetujui bersama oleh DPRD Kota Mataram dan Walikota Mataram disampaikan oleh pimpinan DPRD Kota Mataram kepadaWalikotaMataramuntuk ditetapkan menjadi Peraturan Daerah.

Penyampaian Rancangan Peraturan Daerah tersebut dilakukan dalam jangka waktu paling lambat 7 (tujuh) hari terhitung sejak tanggal persetujuan bersama. Walikota Mataram menetapkan Rancangan Peraturan Daerah dengan membubuhkan tanda tangan paling lambat 30 (tiga puluh) hari sejak Rancangan Peraturan Daerah disetujui bersama oleh DPRD Kota MataramdanWalikotaMataram.

Dalam hal kepala daerah tidak menandatangani Rancangan Perda, maka 
Rancangan Perda tersebut sah menjadi Peraturan Daerah dan wajib diundangkan dalam lembaran daerah. Peraturan Daerah yang telah ditetapkan, selanjutnya diundangkan dengan menempatkannya di dalam lembaran daerah oleh Sekretaris Daerah Kota Mataram, sedangkan penjelasan Peraturan Daerah dicatat di dalam tambahan lembaran daerah. Pengundangan Peraturan daerah tersebut sebagai syarat hukum agar setiap orang mengetahuinya (Pasal 86 ayat (1) UndangUndang Nomor 12 Tahun 2011 tentang Pembentukan Peraturan Perundang-undangan) . Kemudianketentuanlebihlanjut diaturdalamPasal55danPasal56 PeraturanMenteriDalamNegeri Nomor 53 Tahun 2011 tentang Pembentukan Produk Hukum Daerah.

Apabiladihubungkan proses pembentukan peraturan daerah baik melalui inisiatif kepala daerah maupun melalui inisiatif DPRD Kota Matatam, maka indikator yang digunakan untuk menentukan produk hukum yang dihasilkan berkarakter responsif atau ortodoks yaitu dari segi fungsinya hukum, proses pembuatannya dan penafsiran atas sebuah produk hukum, maka Rancangan yang berasal dari inisiatif kepala daerah bersifat positivisinstrumentalis, artinya memuat materi yang lebih merefleksikan visi sosial dan politik pemegang kekuasaan atau memuat materi yang lebih merupakan alat untuk mewujudkan kehendak dan kepentingan program pemerintah (top down). Dari segi proses pembuatannya yang bersifat sentralistik dalam arti lebih didominasi oleh Pemerintah Daerah dalam halini SKPDterkait, kemudiandarisegi penafsiran atas sebuah produk hukumnya memberi peluang luas kepada pemerintah untuk membuat berbagai interpretasi dengan berbagai peraturan lanjutan yang berdasarkan visi sepihak dari pemerintah dan tidak sekedar masalah teknis, hal tersebut jelas terlihat pada ketentuan Pasal 7 Peraturan Daerah Kota Mataram Nomor : 8 tahun 2008 Tentang Rencana Pembangunan Jangka Panjang Daerah (RPJPD) Kota Mataram Tahun 2005-2025, yang pada pokoknya menyatakan sebagai berikut :

"Hal-hal yang mengatur tentang pelaksanaan dan hal lain yang belum diatur dalam Peraturan Daerah ini ditetapkan dengan Keputusan Walikota sesuai dengan Peraturan Perundang-Undangan yang berlaku."

Sedangkan Rancangan Peraturan Daerah yang berasal dari Inisiatif DPRD Kota Mataram bersifat aspiratif, artinya memuat materi-materi yang secara umum sesuai dengan aspirasi atau kehendak masyarakat yang dilayaninya, sehingga produk hukum itu dapat dipandang sebagai kristalisasi dan kehendak masyarakat (bottom up). Dari segi proses pembuatannya yang bersifat partisipatif, yakni mengundang sebanyakbanyaknya partisipasi masyarakat melalui kelompok- 
kelompok sosial dan individu di dalam masyarakat, kemudian dari segi penafsiran atas sebuah produk hukumnya sangat sedikit memberikan peluang untuk dilakukan penafsiran, hal tersebut terlihat jelas pada Peraturan Daerah Kota Mataram Nomor 7 Tahun 2011 Tentang Tata Cara Pendirian, Pengawasan, Pengendalian dan Penyelenggaraan Menara Telekomunikasi, dimana setelah dilakukan pengkajian baik materi maupun substansinyasangatrincidiatur, kalau pun ada yang diatur lebih lanjut dengan Peraturan Walikota hanya sebatas teknis pelaksanaanya saja. Begitu juga halnya dengan ketentuan yang diatur dalam Peraturan Daerah Kota Mataram Nomor 5 Tahun 2012 Tentang Penanggulangan Anak Jalanan, Gelandangan dan Pengemis Di Kota Mataram, sehinggaPeraturanDaerahyang berasal dari inisiatif DPRD Kota Mataram cenderung berkarakter responsif.

\section{SIMPULAN}

Dari uraian pembahasan sebelumnya, maka dapat disimpulkan bahwa dalam Proses pembentukan Peraturan Daerah Pemerintahan Kota Mataram pada tataran pelaksanaannya sudah memberikan ruang partisipasi masyarakat di dalam pembentukannya, akan tetapi memiliki perbedaan yang sangat mendasar, dimana Peraturan Daerah yang berasal dari inisiatif DPRD Kota Mataram cenderung berkarakter responsif karena bersifat aspiratif yang cenderung merespon akan kebutuhan masyarakat (bottom up) dan proses pembuatannya pun bersifat partisipatif, serta dari segi penafsiran maka produk hukumnya memberikan sedikit peluang bagi pemerintah untuk membuat penafsiran sendiri melalui berbagai peraturan pelaksanaan. Sedangkan Peraturan Daerah yang diajukan oleh Kepala Daerah cenderung berkarakter ortodoks karena bersifat positivis-instrumentalis, artinya memuat materi yang lebih merefleksikan visi sosial dan politik pemegang kekuasaan atau memuat materi yang lebih merupakan alat untuk mewujudkan kehendak dan kepentingan program pemerintah (top down). Kemudian proses pembuatannya yang bersifat sentralistik, serta dari segi penafsiran maka produk hukumnya memberi peluang luas kepada pemerintah untuk membuat berbagai interpretasi dengan berbagai peraturan lanjutan.

\section{DAFTAR PUSTAKA}

\section{Buku}

Hamzah Halim dan Kemal Redino Syahrul Putera, 2009, Cara Praktis Menyusun dan Merancang Peraturan Daerah, Kencana Prenada Media Group, Jakarta

Jazim Hamidi, 2008, Panduan Praktis Pembentukan Peraturan Daerah Partisipatif, Prestasi Pustaka, Jakarta

Jazim Hamidi, 2011, Optik Hukum Peraturan Daerah Yang Bermasalah, PT. Prestasi Pustakaraya, Jakarta

Moh. Mahfud MD, 2011, Membangun Politik Hukum Menegakkan Konstitusi, Rajawali Pers PT. Raja Grafindo Persada, Jakarta

Mustaqiem, 2008, Pajak Daerah Dalam Transisi Otonomi Daerah, FH UII Press, Yogyakarta

Rosidin, 2010, Utang, Otonomi Daerah dan Desentralisasi, CV. Pustaka Setia, Bandung

Sarundajang, 2000, Arus Balik Kekuasaan 
D a r m i n | Pembentukan Peraturan Daerah Yang Responsif Melalui Inisiatif DPRD Kota Mataram.

Pusat ke Daerah, Pustaka Sinar Harapan, Jakarta

Sunarno Siswanto, 2008, Hukum

Pemerintahan Daerah di

Indonesia, Sinar Grafika, Jakarta

Maria Soeprapto Farida Indrati, 2007, Ilmu Perundang-Undangan, jenis, fungsi dan materi muatan. Kanisius, Yogjakarta

Lubis Solly, 2009, Пlmu Pengetahuan Perundang-undangan, CV. Mandar Maju, Bandung

\section{Jurnal}

M. Yazid Fathoni, Konsep Keadilan Dalam Pengelolaan dan Pemanfaatan Sumber Daya Alam Menurut Undang-Undang Pokok Agraria Tahun 1960, Jurnal IUS (Hukum dan Keadilan), Vol. I, No. 1, April 2013, http://jurnalius.ac.id/ojs/ index.php/jurnalIUS/article/ view/225/197, diakses tanggal 6 April 2018. hlm. 46 